\title{
Research on the Development Characteristics of Green Energy Industry in Main Developed Countries
}

\author{
Chenglei Xu, Huan Zhou* and Yonghe Sun \\ Kunming University of Science and Technology, 650000 Kunming, China
}

\begin{abstract}
Green energy is regarded as the breakthrough of the fourth technological revolution of mankind, which is highly concerned by the whole world. By analysing the development strategies of major developed countries to promote green energy industry, this paper constructs a theoretical framework from four aspects: government policy, green consumption, technology and capital, so as to summarize the typical characteristics of the development of green energy industry. The study found that government policy and technology are the main driving force for the development of green energy industry in major developed countries, the resource-rich United States leads the industrial development with policy, and the European Union obtains new energy development through policy and technological innovation at the same time. Japan continues to innovate and take the lead in technology to break the limitations of innate conditions. The conclusions of the study will help countries with the same resource base, policy environment and consumption concept to sort out the development ideas of green energy, and provide some reference and reference for the formulation of effective development strategies.
\end{abstract}

\section{Introduction}

Mankind is facing the third transformation of energy structure, that is, the evolution from oil-based energy structure to green energy era [1]. Green energy is also known as new energy, renewable energy or clean energy, and a series of processes around the development, utilization and management of green energy are called green energy industry. Literature research shows that, no matter from the perspective of energy security or environmental requirements, green energy has become an important choice for all countries to implement sustainable development. Around the characteristics of green energy industry, scholars have made a lot of discussions from the characteristics of technology, market and organization, research and development, industrialization and technology, industrialization and other characteristics, and basically reached a consensus. Gang believes that as an emerging industry with strategic significance and public foundation, as well as obvious innovation attributes and competitive characteristics, the new energy industry has a long industrial chain and is highly dependent on science and technology, and its development involves many innovation subjects and complex innovation systems [2]. Tracey believes that the new energy industry has a natural monopoly and has a high threshold for entry [3]. Bishan believes that institutional innovation and personnel training are the basis for the formation of the overall advantage of energy [4]. To sum up, the above research has played a positive role in the development of the green energy industry, but due to the significant differences in economic system, market environment, values and consumption habits among countries around the world, there are relatively few studies on the diversity of the development characteristics of the green energy industry in different countries, lack of systematic carding of development paths, and then cannot formulate targeted guidance strategies for the green energy industry. In view of this, this paper systematically combs the development process and development situation of green energy promoted by developed countries, shows the evolutions of the positioning of green energy in developed countries, and studies the typical characteristic and latest trends in the process of promoting green energy development in developed countries. In view of this, this article systematically sorts out the development history and development status of green energy in developed countries, shows the evolution of green energy positioning in developed countries, and studies the typical characteristics and latest trends in the development of green energy in developed countries, in order to sort out major developed countries The development characteristics of the green energy industry are in line with the latest trends in world development..

\section{The strategic choice of green energy industry in major developed countries}

\subsection{United States: policy Innovation priority}

\footnotetext{
* Corresponding author: 2862894368@qq.com
} 
In the process of developing new energy, the US government guides and develops the infrastructure investment of new energy from three core links: establishing bill, policy pricing and tax economic compensation. In the establishment of relevant legislation and measures, the most important thing is to amend the 1986 domestic tax Act, formulate the Energy tax incentive Act of 2003, and establish a tax incentive mechanism for energy green production. In addition to tax incentives, the Bush administration has also passed energy laws such as the 2005 US Energy Policy Act, the 2006 Advanced Energy Initiative, and the 2007 Energy Independence and Security Act. The state government has also introduced a large number of energy policy bills, and substantial breakthroughs have been made in the implementation of the energy green strategy. Policy pricing guidance and incentives are provided by the government to protect against the risks caused by the high cost of new energy technologies and market development in the initial stage. In terms of tax economic compensation, the Energy tax incentive Act of 2003 is adopted to implement tax exemption for alternative energy-related industries, and the Energy Policy Act of 2005 provides tax incentives for hybrid vehicles and tax credits for the construction of household solar systems. In the United States, which is rich in solar and wind natural resources, wind energy is already more price competitive than fossil fuels. The United States has extended the wind energy production tax credit bill, and the photovoltaic industry has also benefited from the investment tax credit. As shown in Figure 1, in the past five years, the installed capacity of wind power and photovoltaic in the United States has maintained a steady growth trend, and the development trend is good.

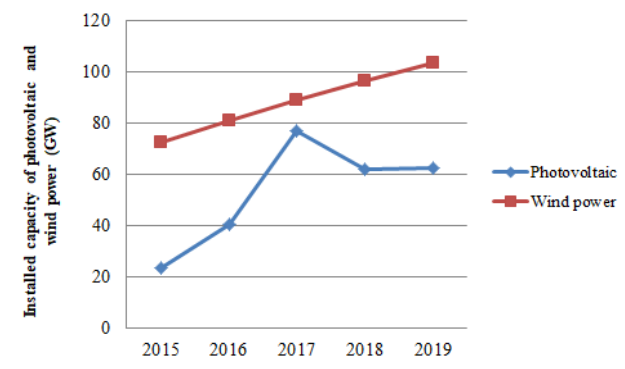

Fig. 1, Installed capacity of wind power and photovoltaic in the US in the past five years

\subsection{EU: policy and technological innovation at the same time}

In the field of renewable energy, the European Union has taken the lead in formulating the policies and laws needed to promote the development of renewable energy, and has become a pioneer in the development and implementation of modern renewable energy technologies. Green papers and circulars have been issued in terms of policies, which are reflected in regulations and directives in secondary legislation. European laws and policies related to clean energy power generation are consistent with existing policies in other areas, and seek continuous improvement and improvement. EU countries also actively revise their domestic laws and constantly coordinate cooperation at home and abroad. The European Union has actively increased its investment in R \& D and innovation of new energy technologies, mainly from the two aspects of R \& D innovation, achievement transformation and industrialization. In the context of global energy transformation, many countries have begun to transition their energy systems to more sustainable energy technology supply systems based on renewable energy. As shown in Figure 2, the European Union has been in the lead in energy investment in recent years, but the United States and China still have a lot of room for development.

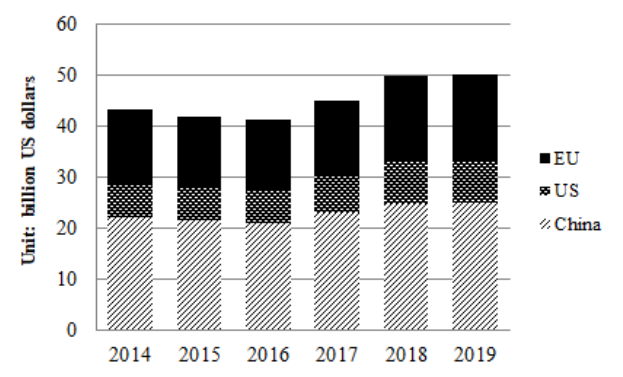

Fig. 2, Energy investment of Europe, the United States and China in 2014-2019

\subsection{Japan: giving priority to technological innovation}

Many of the world's leading technologies in the field of new energy in Japan are closely related to the Japanese government's goal understanding, planning, promotion and application of energy technology. To determine the goal of the development and utilization of new energy technology, Japan has strengthened the development and utilization of new energy under the basic goals of energy security, economic growth and environmental protection, so that its dependence on oil is significantly reduced. To formulate plans and action plans for the promotion of new energy technologies, the development of Japan's new energy industry has always been promoted through planning and legal means. To promote the promotion and application of new energy technologies, first of all, a large amount of money should be invested to support the research and development of new energy technologies. The "New Sunshine Project" allocates more than 57 billion yen a year to study new energy technologies, energy transmission and storage technologies, and so on. Second, we will encourage the government and social organizations to take the lead in the use of new energy. With the rise of a new round of industrial revolution, major countries and regions in the world regard energy technology as a breakthrough in a new round of scientific and technological revolution. In the past five years, the United States, Japan and the European Union have accelerated the application of energy patent technology, as shown in Figure 3. Japan has a certain advantage in energy technology patents, which also indicates that green and low-carbon energy technology 
must be the main direction of energy industry development in the future.

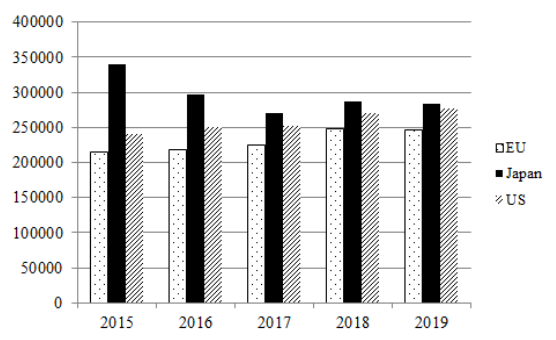

Fig. 3, The number of energy patents in Europe, Japan and the United States in the past five years

\section{The analytical framework of the characteristics of green energy industry in major developed countries}

In the existing literature, there are few in-depth studies on the influencing factors of green energy industry, and the existing literature is basically based on diamond model or GEM model. So far, all these countries have taken very different paths, because the energy transformation depends on a number of variables, such as the political and social environment, geographical location or technological inputs. Based on this, this paper selects government policy, green consumption, capital and technological factors to construct the analysis framework of green energy industry characteristics and puts forward the related research progress, as shown in Table 1.

Table 1, Analysis framework of development characteristics of green energy industry

\begin{tabular}{|c|c|c|c|}
\hline $\begin{array}{l}\text { First-level } \\
\text { index }\end{array}$ & Secondary index & $\begin{array}{c}\text { Major } \\
\text { scholars }\end{array}$ & Index research content \\
\hline $\begin{array}{c}\text { A } \\
\text { Government } \\
\text { policy }\end{array}$ & $\begin{array}{l}\text { A1: Target guidance } \\
\text { A2: Price incentive } \\
\text { A3: Financial subsidy } \\
\text { A4: Tax preference } \\
\text { A5: Credit support } \\
\text { A6: Export incentives } \\
\text { A7: Scientific research and } \\
\text { industrialization } \\
\text { A8: Administrative } \\
\text { intervention }\end{array}$ & $\begin{array}{l}\text { Huan Zhang } \\
\text { [5], Xue } \\
\text { Jing Yan [6] } \\
\text { Reza } \\
\text { Nadimi [7] }\end{array}$ & $\begin{array}{l}\text { A1: The development goal is the basis and purpose of establishing } \\
\text { specific policies. } \\
\text { A2: Through price concessions to ensure the cost of energy products. } \\
\text { A3: Economic incentives subsidized by investment, products and users. } \\
\text { A4: Encouragement to give tax relief or relief. } \\
\text { A5: Lighten the burden on the enterprise to repay the interest of the } \\
\text { current period. } \\
\text { A6: Make use of foreign aid channels to expand overseas markets. } \\
\text { A7: Provide technical guidance, R \& D funds and subsidies and other } \\
\text { support. } \\
\text { A8: To ensure the effective implementation of government policies } \\
\text { through administrative intervention. }\end{array}$ \\
\hline $\begin{array}{c}\text { B Green } \\
\text { consumption }\end{array}$ & $\begin{array}{l}\text { B1: Led by the government } \\
\text { B2: Enterprise promotion } \\
\text { B3: Consumer participation }\end{array}$ & $\begin{array}{c}\text { Bang Wang } \\
{[8]}\end{array}$ & $\begin{array}{l}\text { B1: The government is responsible for legislating and enforcing laws and } \\
\text { regulations and plays a leading role. } \\
\text { B2: Enterprises meet the needs of consumers and develop green } \\
\text { products. } \\
\text { B3: Consumers change their consumption patterns and values. }\end{array}$ \\
\hline C Capital & $\begin{array}{l}\text { C1: Human capital } \\
\text { C2: Economic capital } \\
\text { C3: Social capital }\end{array}$ & $\begin{array}{c}\text { Matthew } \\
\text { Greaves[9] }\end{array}$ & $\begin{array}{l}\mathrm{C} 1 \text { : Human capital is the key condition for the development of green } \\
\text { energy industry. } \\
\mathrm{C} 2 \text { : Economic capital drives the development of green energy economy. } \\
\text { C3: Social capital strengthens the links between various energy } \\
\text { industries. }\end{array}$ \\
\hline D Technical & $\begin{array}{l}\text { D1: Technology Research } \\
\text { and Development } \\
\text { D2: Technology diffusion } \\
\text { D3: Application of } \\
\text { technology }\end{array}$ & $\begin{array}{c}\text { Qunli } \\
\text { Zhang[10] }\end{array}$ & $\begin{array}{l}\text { D1: The stage of planning and development of energy technology. } \\
\text { D2: The process in which technical information is disseminated, } \\
\text { digested, and absorbed. } \\
\text { D3: The practical application stage of energy technology in various } \\
\text { fields. }\end{array}$ \\
\hline
\end{tabular}

\section{Identification of the development characteristics of green energy industry in major developed countries}

In order to effectively sort out the development characteristics of green energy industry in major developed countries, on the basis of the analysis framework of four indicators: policy, consumption, capital and technology, combined with the above new energy strategy choices of the United States, the European Union and Japan, as well as the relevant data in the U.S. Department of Energy Information (EIA), Eurostat and BP World Energy Statistical Yearbook. This paper combs and summarizes the development characteristics of the green energy industry in the main developed countries of the United States, the European Union and Japan around the four aspects of government policy, green consumption, capital and technology. The development characteristics of green energy industry in major developed countries can be obtained as shown in Table 1. In the table, D1 D4 represents the major developed countries, the United States, the European Union and Japan, P1 P4 represents the analytical framework of the development characteristics of the green energy industry, and P11 P43 represents the main development characteristic indicators. The corresponding development characteristics of the green energy industry are expressed by "characteristics" and "characteristics": "characteristics" means strong, "weak" means weak and "-" indicates that there are no 
corresponding development characteristics for the time being.

Table 2, Development characteristics of green energy industry in major developed countries

\begin{tabular}{|c|c|c|c|c|}
\hline $\begin{array}{l}\text { Analytical } \\
\text { framework }\end{array}$ & Main index & D1 US & D2 EU & D3 Japan \\
\hline \multirow{8}{*}{$\begin{array}{l}\text { P1 Government } \\
\text { policy }\end{array}$} & P11 Target guidance & $\star$ & $\star$ & $\star$ \\
\hline & P12 Price incentive & $\star$ & $\star$ & - \\
\hline & P13 Financial subsidy & $\star$ & $\star$ & $\star$ \\
\hline & P14 Tax preference & $\star$ & $\star$ & $\star$ \\
\hline & P15 Credit support & $\star$ & $\star$ & $\dot{s}$ \\
\hline & P16 Export incentives & $\star$ & $\star$ & $\sum$ \\
\hline & P17 Scientific research and industrialization & $\star$ & $\star$ & $\star$ \\
\hline & P18 Administrative intervention & 交 & $\star$ & 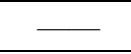 \\
\hline \multirow{3}{*}{$\begin{array}{l}\text { P2 Green } \\
\text { consumption }\end{array}$} & P21 Led by the government & $\star$ & 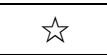 & $\star$ \\
\hline & P22 Enterprise promotion & 岤 & 岤 & $\star$ \\
\hline & P23 Consumer participation & $\dot{s}$ & $\star$ & 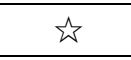 \\
\hline \multirow{3}{*}{ P3 Capital } & P31 Human capital & $\star$ & 岤 & 岤 \\
\hline & P32 Economic capital & 弥 & 弥 & $\star$ \\
\hline & P33 Social capital & $\dot{s}$ & $\star$ & $\hat{s}$ \\
\hline \multirow{3}{*}{$\begin{array}{l}\text { P43 Application } \\
\text { of technology }\end{array}$} & P41 Technology Research and Development & $\star$ & $\star$ & $\star$ \\
\hline & P42 Technology diffusion & 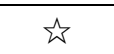 & $\star$ & $\star$ \\
\hline & P43 Application of technology & 必 & $\star$ & $\star$ \\
\hline
\end{tabular}

According to the analysis of Table 2, the development of green energy industry in major developed countries is faced with the interactive promotion of government policies, green consumption, capital and technology. However, due to the diversity of green energy industry in major developed countries, it is found that policy support is the basis for the development of green energy industry in major developed countries, and technological innovation is an important starting point to achieve energy policy objectives. The energy industry with rich energy resources and high consumption needs continuous and innovative energy policies to optimize the development environment of the new energy industry and provide guarantee for the sustainable development of the green energy industry. The energy industry under the difference of economic development level and resource endowment needs to adhere to the development strategy of policy innovation and technology leadership to implement the development goal, unify the green energy market under the action of policy, and reduce the development gap in technology. Further enhance the development space of the overall green energy industry. The energy industry, which is limited by the basic conditions of realistic energy, can also find another way in the field of technology development and innovation, break its own industrial restrictions and realize the transformation of green energy industry.

\section{Conclusions}

The energy industry will lead the development direction of the world economy and drive new changes in human society. However, the development of green energy industry in different countries is faced with different policies, technologies and other development environments, showing different development characteristics. Systematically sort out the research on the development characteristics of green energy industry in major developed countries, and analyse the countries with different energy development bases. It is of great significance to clarify the development ideas of green energy, clarify the characteristics of green energy construction, and then formulate specific guiding strategies.

\section{Acknowledge}

This paper is sponsoned by School-land cooperation project of Chinese Academy of Engineering (2020YNZH3) and Key projects of Humanities and Social Sciences Research on Educational Cooperation between Colleges and Universities in Yunnan Province.

\section{References}

1. Cashin Michael G, Inter Christian, Palmer Eric. Natural Gas \&amp; Electricity, 34 (2017)

2. Wu, Gang, M. Zeng, L. Peng. In Renewable and Sustainable Energy Reviews, 53 (2016)

3. Tracey D, Marc O, Tim N. Energy Policy, 123 (2018)

4. Wu Bishan. Energy Sources, Part A: Recovery, Utilization, and Environmental Effects, 42 (2020)

5. Huan Zhang, Xinxin Xu, Wei Liu. Managerial and Decision Economics, 41 (2020)

6. Xue Jing Yan, Liu Geng Yuan. The journal of applied ecology, 29 (2018) 
7. Reza Nadimi, Koji Tokimatsu, Kunio Yoshikawa. Energy Procedia, 142 (2017)

8. Lina Barbulescu. Journal of Environmental Management, 204 (2017)

9. Matthew Greaves. Canadian Journal of Communication, 42 (2017)

10. Qunli Zhang, Donghan Sun, Mingshuang Wang. Energy Procedia, 142 (2017) 